\title{
Relationship between Delayed Leaf Senescence (Stay-Green) and Agronomic and Physiological Characters in Maize (Zea mays L.)
}

\author{
Nadia Chibane ${ }^{1}$ (D), Marlon Caicedo ${ }^{2}$, Susana Martinez ${ }^{3}$, Purificación Marcet ${ }^{4}$, Pedro Revilla ${ }^{1}$ (D) \\ and Bernardo Ordás ${ }^{1, *}$ \\ 1 Misión Biológica de Galicia (CSIC), Carballeira, 8, 36080 Salcedo, Spain; nchibane@mbg.csic.es (N.C.); \\ previlla@mbg.csic.es (P.R.) \\ 2 Instituto Nacional de Investigaciones Agropecuarias (INIAP), Quito 170315, Ecuador; \\ marlon.caicedo@iniap.gob.ec \\ 3 3edata, I+D, Centro de Iniciativas Empresariales, Fundación CEL, O Palomar s/n, 27004 Lugo, Spain; \\ susana.martinez@3edata.es \\ 4 Area de Edafología y Química Agricola, Facultad de Ciencias, Universidad de Vigo, Lagoas-Marcosende, \\ 36200 Vigo, Spain; marcet@uvigo.es \\ * Correspondence: bordas@mbg.csic.es
}

Citation: Chibane, N.; Caicedo, M.; Martinez, S.; Marcet, P.; Revilla, P.; Ordás, B. Relationship between Delayed Leaf Senescence (Stay-Green) and Agronomic and Physiological Characters in Maize (Zea mays L.). Agronomy 2021, 11, 276.

https://doi.org/10.3390/ agronomy11020276

Academic Editor: Sara Di Lonardo Received: 31 December 2020

Accepted: 29 January 2021

Published: 2 February 2021

Publisher's Note: MDPI stays neutral with regard to jurisdictional claims in published maps and institutional affiliations.

Copyright: (c) 2021 by the authors. Licensee MDPI, Basel, Switzerland. This article is an open access article distributed under the terms and conditions of the Creative Commons Attribution (CC BY) license (https:// creativecommons.org/licenses/by/ $4.0 /)$.

\begin{abstract}
Stay-green (SG) is a term used to describe genotypes that have delayed leaf senescence as compared to reference genotypes. SG could be favorable for grain yield, silage yield and quality, double exploitation (grain for feed and stover for bioenergy), stress resistance, etc. However, some studies show contradictory results regarding the influence of senescence or SG in the uptake and remobilization of nutrients and the yield and moisture of stover and grain. This experiment is aimed to study the impact of senescence in grain and stover yield and moisture in inbred lines of maize and assess the potential of SG genotypes for double exploitation. We also study the influence of senescence in the uptake of $\mathrm{N}$ and remobilization of dry matter and $\mathrm{N}$ from stover to grain. We evaluated 16 maize inbred lines with contrasting expression of senescence in the field at two locations in Galicia in 2017. We confirmed that SG is functional, meaning that the SG genotypes maintained photosynthesis activity for a lengthy period. Coordinated with a delayed senescence, the grain filling of the SG genotypes was 9 days longer than NSG genotypes. SG genotypes took up more N after flowering, although the remobilization of $\mathrm{N}$ and, in general, of dry matter from stover to kernels was less efficient. However, the higher uptake compensated the poor remobilization, and the final effect of SG on the N content of the kernels was favorable. SG was also favorable for kernel weight and the kernels of SG genotypes were $20 \%$ heavier than for NSG. The stover yield was also higher in the SG genotypes, indicating a potential of SG for breeding for double purpose (grain for feed and stover for bioenergy).
\end{abstract}

Keywords: maize; stay-green (SG); yield; chlorophyll content; chlorophyll fluorescence; nitrogen; plant senescence

\section{Introduction}

Senescence is an active phase of plant development involving degradation and remobilization processes [1]. Canopy senescence is often used by breeders as an indicator of the phenological/physiological state of a crop after flowering since it correlates with physiological maturity of grains [2]. Under optimal conditions, the onset and duration of senescence are predictable and closely related to the phenological development of the crop [3]. Leaf senescence is a highly regulated process during which nutrients are transferred from the senescent leaf to other parts of the plant, leading to leaf death [4]. During senescence, the leaf yellows as chlorophyll degrades and photosynthesis is reduced [5]. Leaf senescence is simultaneous to the grain filling period in maize (Zea mays L.) with a higher rate of 
senescence in the second half of the grain filling according to estimations of [6] in three hybrids. These authors observed a top-bottom profile of leaf senescence with the leaves close to the ear being the last to senesce. The leave senescence/grain filling period is a critical period when many processes can influence the final grain yield [7]. Thus, about $50 \%$ of total dry matter in maize at maturity is obtained during the post silking period $[8,9]$. It has also been shown that maize plants continue to take up $\mathrm{N}$ even beyond three weeks post-silking [10], and $35-55 \%$ of grain $N$ is contributed by post-silking $N$ uptake [11,12].

Delay in senescence or stay-green (SG) is the general term given to genotypes in which senescence is delayed compared to standard reference genotypes [13]. Stay-green can be divided into several categories by examining the pattern of its physiological dynamic. Staygreen $A$ and $B$ are called functional SG, which refers to phenotypes that maintain their green color, chlorophyll activity, and photosynthetic rate [13,14]. Type A stay-green maintains consistent chlorophyll and photosynthesis until shortly before the physiological maturity of grain, followed by a sudden decline. For stay-green type B, senescence occurs at a slow rate, and plants exhibit a slow rate of decline of chlorophyll contents and photosynthetic rate [15]. For cosmetic or non-functional SG, the plants maintain the green color or chlorophyll activity, but the photosynthetic capacity decreases or disappears [15].

In maize, senescence is considered a key feature in the improvement of grain yield [16]. Functional SG varieties perform photosynthesis and are potentially able to incorporate $\mathrm{C}$ and $\mathrm{N}$ during a lengthy period of time $[1,17]$ which could be positive for several traits, such as grain yield, silage yield and quality, stress resistance, etc. [13,18-20]. A delayed senescence could be also favorable for varieties that have a double purpose: grain for feed and leaves, stems, and cobs for bioenergy [21], although there is little experimental information to corroborate this hypothesis in maize or other crops. Thus, SG genotypes could constitute a potential germplasm source for the genetic improvement of important crops [22]. However, a longer life for the leaves could negatively influence the remobilization of nutrients from leaves or stems and reduce the availability of $\mathrm{N}$ for the grains that could be detrimental for grain yield and/or quality [23,24]. This was called the "dilemma of senescence" [25]. However, Chen et al. [26] found that some maize hybrids have both better uptake and remobilization in contradiction with the "dilemma of senescence".

The aims of this study were to study the impact of senescence in grain and stover yield and moisture in inbred lines of maize and assess the potential of SG genotypes for the double exploitation: grain for feed and stover for bioenergy. We also study the influence of senescence in the uptake of $\mathrm{N}$ and remobilization of matter and $\mathrm{N}$ from stover to grain.

\section{Materials and Methods}

\subsection{Locations and Plant Materials}

The experiment was performed at two locations in Spain in 2017, Tomeza (latitude $42.40^{\circ} \mathrm{N}$ and longitude $8.63^{\circ} \mathrm{W}$ ) and Xinzo de Limia (latitude $42.07^{\circ} \mathrm{N}$ and longitude $7.73^{\circ} \mathrm{W}$ ). Sixteen maize inbred lines were used in this study, including 8 SG and 8 NSG lines. Some lines belong to the main heterotic groups used in temperate breeding, such as European Flint, Iodent, Lancaster or Stiff Stalk, while others are from mixed or unknown origin. Most of them are lines with expired Plant Variety Protection certificates (exPVP) which are a source of elite and relevant germplasm to be used by breeders or researchers [27]. The lines were selected for their senescence expression based on preliminary evaluations without replications. The 16 inbred lines can be grouped into four different flowering groups, from the earliest to latest flowering time (Table 1). 
Table 1. Senescence group, flowering groups, Heterotic groups and origin of the 16 inbred lines of maize used in this study.

\begin{tabular}{|c|c|c|c|c|}
\hline $\begin{array}{l}\text { Inbred } \\
\text { Lines }\end{array}$ & GS & FG & Heterotic Group & Origen \\
\hline F030 & SG & 1 & European Flint & University of Hohenheim \\
\hline F05405 & SG & 2 & Unknown & INRA \\
\hline PHTE4 & SG & 2 & PHJ40/Other SS * & exPVP PI 9400094 \\
\hline EC402 & SG & 3 & Stiff Stalk Synthetic & $\begin{array}{l}\text { Centro de Investigaciones Agrarias } \\
\text { de Mabegondo (Xunta de Galicia) }\end{array}$ \\
\hline PHK76 & SG & 3 & B37/Lancaster/Iodent * & exPVP PI 601496 \\
\hline PHBW8 & SG & 3 & PHJ40/Other SS * & exPVP PI 559936 \\
\hline PHW79 & SG & 4 & Oh7/Midland ** & exPVP PI 601576 \\
\hline PHP38 & SG & 1 & B37/PHG39* & exPVP PI 543845 \\
\hline P033 & NSG & 2 & Iodent & University of Hohenheim \\
\hline EZ59 & NSG & 2 & European Fllint & $\begin{array}{l}\text { Estación Experimental de Aula Dei } \\
\text { (CSIC) }\end{array}$ \\
\hline OQ403 & NSG & 3 & Pioneer 3901 hybrid X K81-336 & exPVP PI 559920 \\
\hline PHG47 & NSG & 3 & Lancaster * & exPVP PI 601318 \\
\hline SD46 & NSG & 4 & Pioneer hybrid 3709 & South Dakota University \\
\hline B73 & NSG & 4 & & \\
\hline PHT11 & NSG & 4 & B37/PHG39 * & exPVP PI 548807 \\
\hline PHM10 & NSG & 4 & B37/PHG39 * & exPVP PI 601778 \\
\hline
\end{tabular}

FG: flowering groups (1: very early; 2: early; 3: medium; 4 : late flowering date) (references: ${ }^{*}$ [27] and ${ }^{* *}$ [28]); GS: groups of senescence.

\subsection{Experimental Design}

The experimental layout in each location was a completely randomized block design with eight replications. The soil texture in both locations is granular sandy loam with a high content of organic matter. The climate is mild oceanic, and the distribution of temperature and precipitation during the experimental season is described in Figure 1 from May to October. One seed was planted per hill, the distance intra-row was $0.21 \mathrm{~m}$ and inter-row was $0.8 \mathrm{~m}$, with an average final plant density of 60,000 plants ha $^{-1}$, and each inbred line had 4 rows at around $3 \mathrm{~m}$ in length. The soil texture was granular sandy loam with a high content of organic matter of $3.74 \%$ and $3.89 \%$ in Tomeza and Xinzo location, respectively. For fertilization treatment, prior to sowing for each location, $90 \mathrm{~kg} \mathrm{ha}^{-1}$ of $\mathrm{N}$ fertilization was applied. An additional fertilization with $45 \mathrm{~kg} \mathrm{ha}^{-1}$ was applied at the V4-V5 stage. N was applied as ammonium nitrate $(27 \%)$.

The trials were kept weed free and different insect attacks were controlled with the application of herbicides (pendimethalin 33\% and sulcotrione 30\%), and insecticides (lambda-cihalotrin 10\%).

\subsection{Field Measurements}

In each location, the net photosynthetic rate was measured from flowering time to total leaf senescence by using an LI-6400XT Portable Photosynthesis System (Li-Cor Inc., Lincoln, NE, USA). Relative leaf chlorophyll content (SPAD) was estimated by using a hand-held CCM-200 Chlorophyll Content Meter (Opti-Sciences, Tyngsboro, MA, USA), and quantum efficiency of photosystem II Fv/Fm was recorded by using an OS-30p Chlorophyll Fluorometer (Opti-Sciences, Tyngsboro, MA, USA). Measurements of chlorophyll content and $\mathrm{Fv} / \mathrm{Fm}$ were taken regularly every 15 days in the leaf that bore the principal ear for 5 plants, whereas the photosynthetic activity was measured monthly in the leaf that bore the principal ear of 3 plants. Days to silking were recorded as the number of days from 
planting to the time when $50 \%$ of the plants showed emerged silks. Days to physiological maturity were estimated by the presence of a black layer in the grain. It was detected using at least 5 ears per inbred line and identified by visual analysis of a thin black layer observed in the seed base, according to Daynard and Duncan (1969). At maturity, 12 plants were harvested randomly from the central rows of each inbred line. Principal and secondary ears of those 12 plants were harvested separately. For the principal ears, grain and cobs of 7 randomly sampled ears were separated and weighed fresh and after being dried at $60{ }^{\circ} \mathrm{C}$ for 5 days. Three hundred dry kernels from each inbred line were weighted to estimate the 1000-kernel weight.

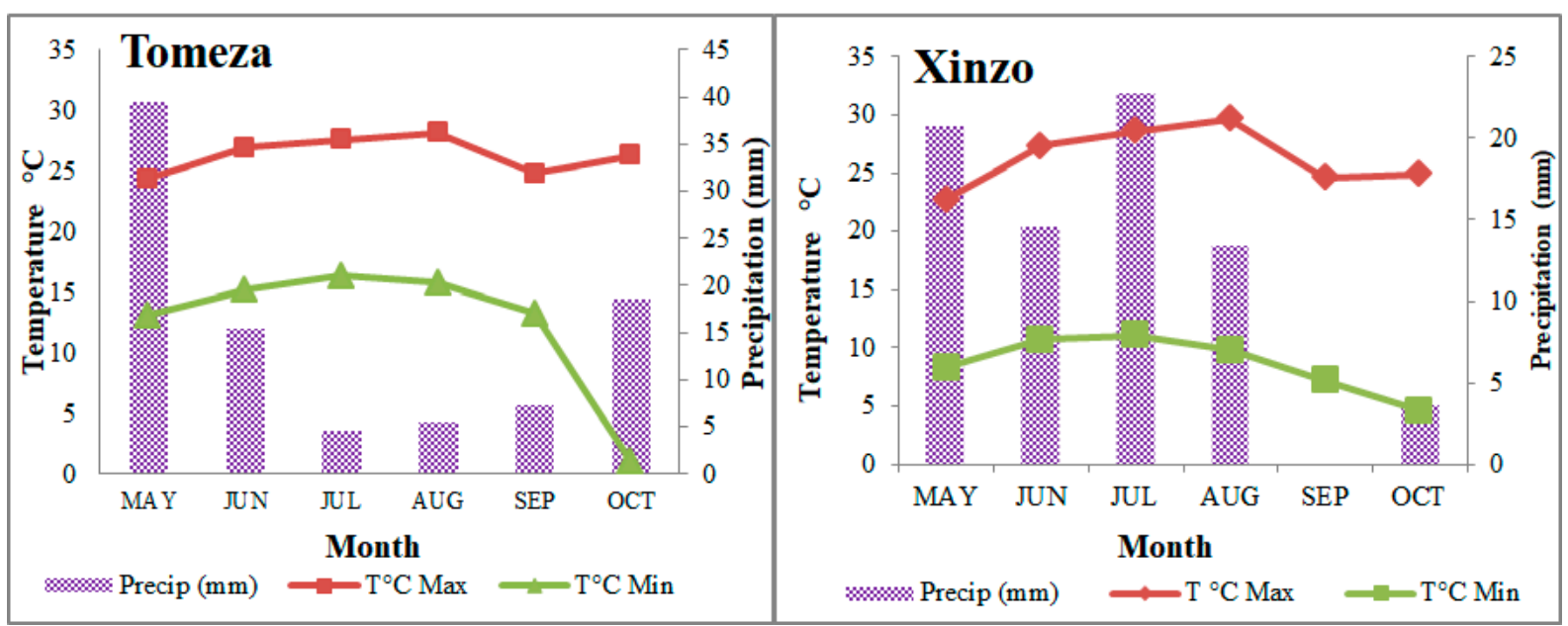

Figure 1. Meteorological conditions during the experimental season in both locations used in this study.

Secondary ears were weighed fresh and after being dried at $60{ }^{\circ} \mathrm{C}$ for 5 days to determine the dry weight. On the other hand, for whole vegetative part or stover (leaves + stem) of plants at flowering time, 5 plants were harvested randomly for each inbred line and weighed before and after drying to measure fresh (SFWF) and dry weight (SDWF). The same operation was performed at harvest time (SWH). The amount of stover that is not remobilized (gplant ${ }^{-1}$ ) is directly the dry weight of the stover at harvest (SDWH_NR), while the stover remobilized (SDWH_R) $\left(\right.$ gplant $\left.^{-1}\right)$ is the difference between the weight of the stover at flowering and harvest.

Nitrogen and carbon concentrations were measured at flowering and harvest time in the plant stover and in the kernels using elemental analysis (Flash EAI112 series). Other variables were estimated from those basic values. The following variables related to the $\mathrm{N}$ in the whole plant were calculated: total $\mathrm{N}(\mathrm{TN})\left(\right.$ gplant $\left.^{-1}\right)$, which is the total amount of $\mathrm{N}$ uptake by the whole plant, was estimated as the sum of the stover and kernel $\mathrm{N}$ at harvest; $\mathrm{N}$ uptake until flowering (TN_AT) $\left(\right.$ gplant $\left.^{-1}\right)$ is directly the content of $\mathrm{N}$ in the plant stover at flowering; $N$ uptake after flowering (TN_AF) $\left(\right.$ gplant $\left.^{-1}\right)$ is the difference between the total $\mathrm{N}$ and the $\mathrm{N}$ uptake until flowering. The percentage of $\mathrm{N}$ uptake before and after flowering with respect to the total $\mathrm{N}$ uptake was also calculated. In addition, the following variables related to the stover were estimated: $\mathrm{N}$ of the stover not remobilized to the grain (SN_NR) (gplant $^{-1}$ ) is directly the N content of the stover at harvest; $\mathrm{N}$ of the stover remobilized to the grain (SN_R) $\left(\right.$ gplant $\left.^{-1}\right)$ is the difference between the $\mathrm{N}$ content at flowering and the $\mathrm{N}$ content of the stover at harvest. The percentage of $\mathrm{N}$ of the stover remobilized and not remobilized to the grain with respect to the $\mathrm{N}$ content of the stover at flowering was calculated. Finally, regarding the kernels, the percentage of $\mathrm{N}$ of the kernel that was derived from remobilized $\mathrm{N}$ was estimated as the $\mathrm{N}$ of the stover remobilized to the grain divided by the $\mathrm{N}$ content of the kernel (KN_R); the percentage of $\mathrm{N}$ of the kernel that was derived from $\mathrm{N}$ uptake after flowering was estimated as the $\mathrm{N}$ uptake after flowering divided by the $\mathrm{N}$ content of the kernel. 


\subsection{Statistical Analyses}

Individual and combined analyses of variance were carried out for each trait using the MIXED procedure of SAS University Edition. Replications and locations were considered random factors and genotypes fixed factors. Mean separation tests and standard error for each trait were performed using the LS means test of SAS proc-MIXED for both location together discussed in this article and specific analysis for each location cited in the (Supplementary Materials: Table S3-S9). All genotypes were compared and a contrast between SG genotypes and NSG genotypes was carried out for physiologic and agronomic traits.

\section{Results}

The results of the combined analysis of variance showed significant differences ( $p \leq 0.05$ and $p \leq 0.01$ ) between SG and NSG genotypes for most of the characteristics evaluated (Supplementary Tables S1 and S2).

\subsection{Photosynthetic Rate, Chlorophyll Content, and Quantum Efficiency of PSII (Fv/Fm)}

The chlorophyll content and photosynthetic rate in leaves of all tested inbred maize lines decreased consistently from a maximum soon after silking to a minimum at physiological maturity. The decrease in both traits 15 days after flowering indicates the beginning of leaf senescence (Figures 2 and 3). However, the decrease in both chlorophyll content and photosynthetic rate in stay-green genotypes was significantly lower than those of non-staygreen genotypes $(p \leq 0.05)$ which indicates that the stay-green of these inbred lines is a functional stay-green. The maximum chlorophyll and photosynthetic values were recorded at the silk stage for both types of genotypes (Figures 2 and 3). During the whole grain filling period, the SG genotypes had chlorophyll content and photosynthetic values higher than the corresponding values in the NSG. Photosynthetic rates decreased at a higher rate than chlorophyll content during the grain filling period. The inbred lines PHW79 and PHP38 maintained their photosynthetic activity and high content of chlorophyll after 60 days. PHW79 maintained both chlorophyll content and photosynthetic activity above zero at 75 days after flowering. The quantum efficiency of PSII Fv / Fm decreased continuously 45 days after flowering time for all genotypes, indicating the beginning of leaf senescence. No significant difference was observed between SG and NSG for quantum efficiency of PSII Fv/Fm during the period of 45 days subsequent to flowering. However, after 45 days, the decrease in Fv / Fm was faster for NSG genotypes than for SG genotypes. The quantum efficiency of PSII Fv /Fm of PHW79 and P030 remained above zero 75 days after flowering time, contrarily to other genotypes that lost their activity after 60 days (Figure 4).

The stover weight of the SG genotypes at harvest was significantly higher than for the NSG genotypes because the NSG genotypes remobilized $15 \%$ of the biomass, while in the SG genotypes, the net remobilization of biomass was negligible (Figure 5A). Thus, the stover weight generally decreased from flowering to harvest in NSG genotypes, but increased in SG genotypes, particularly in the most extreme SG genotypes PHP38 and PHW79 (Supplementary Table S1). The comparison between SG vs. NSG genotypes was significant for both SDWH_NR and SDWH_R, with $p$-value $\leq 0.01$ (Figure 5A). Additionally, for the $1000 \mathrm{~g}$ and cob weight, the difference between SG vs. NSG was significant ( $p$-value $\leq 0.01$ ). 


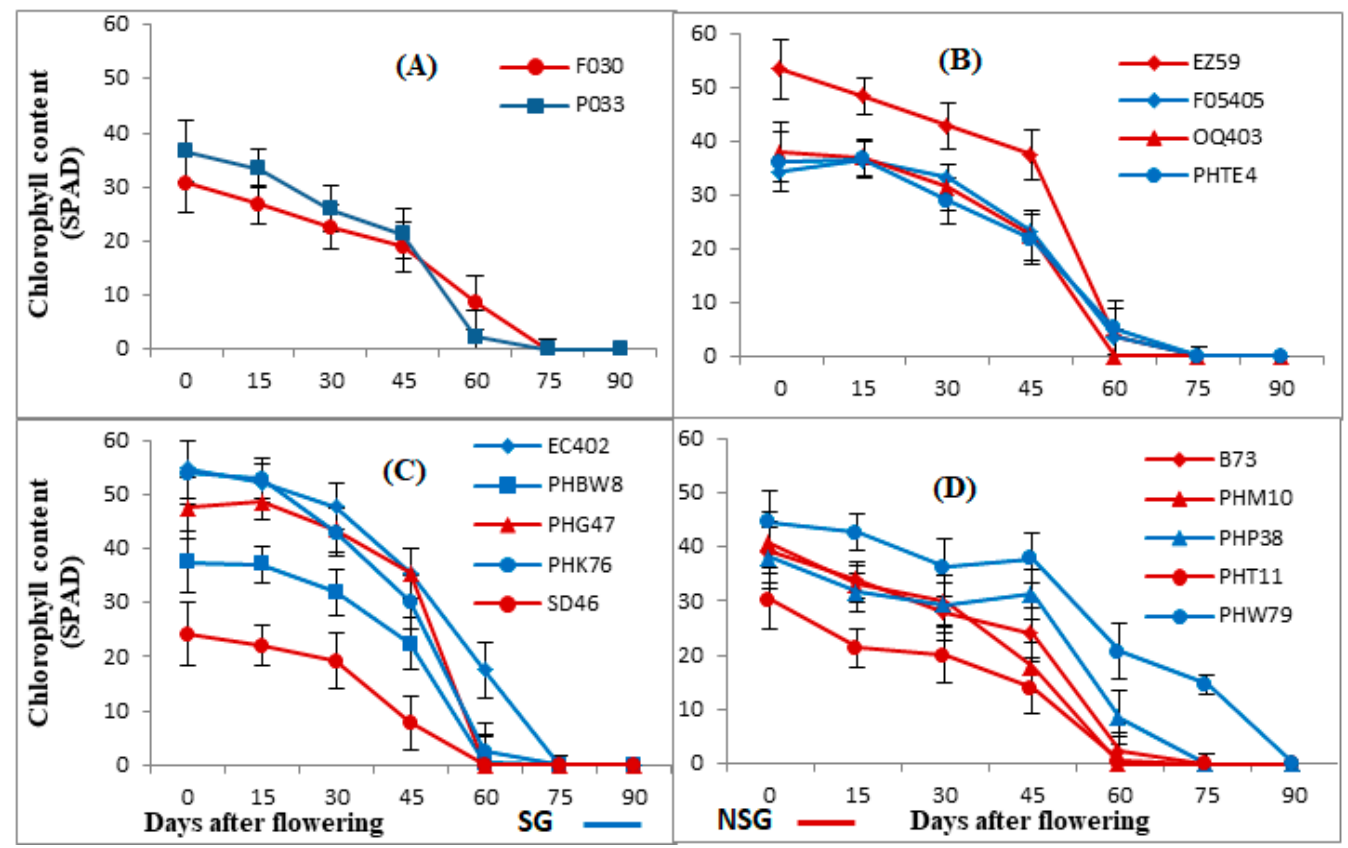

Figure 2. Chlorophyll content of 16 maize inbred lines of four flowering groups from flowering time, evaluated in 2017 in two locations in Galicia. (A,B,C,D) present each flowering group: very early, early, medium, and late flowering, respectively; SG: stay-green genotype. NSG: non-stay-green. Means \pm std error are presented.

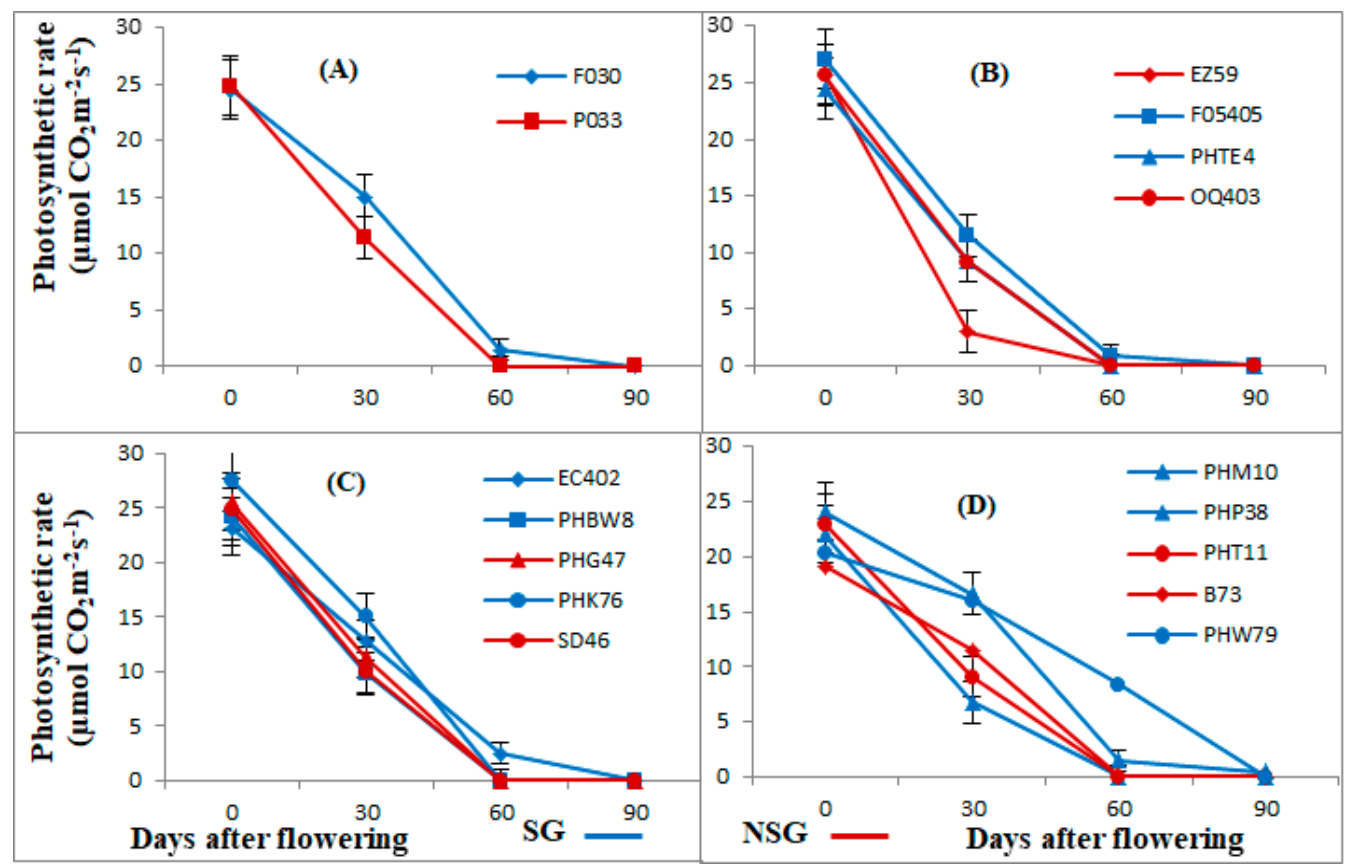

Figure 3. Photosynthetic rate of 16 maize inbred lines of four flowering groups from flowering time, evaluated in 2017 in two locations in Galicia. (A,B,C,D) present each flowering group: very early, early, medium, and late flowering, respectively; SG: stay-green genotype. NSG: non-stay-green. Means \pm std error are presented. 


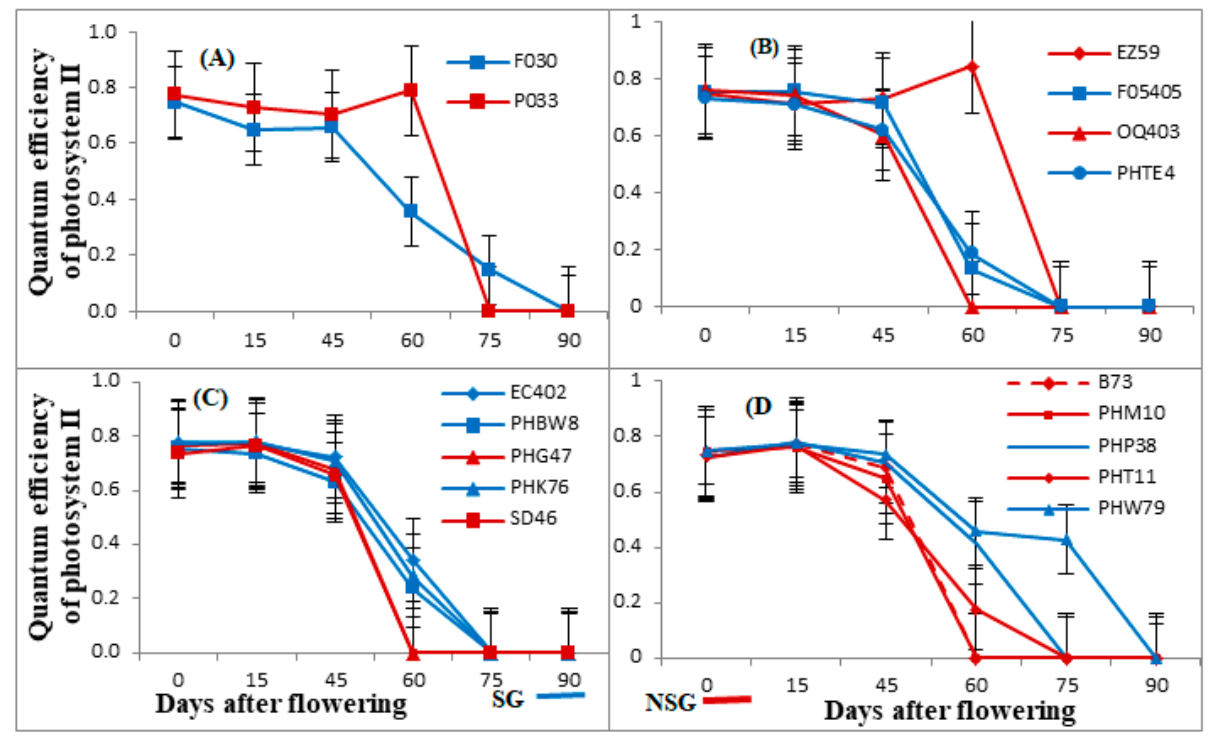

Figure 4. Quantum efficiency of photosystem II (Fv/Fm) from flowering time of 16 maize inbred lines of four flowering groups, evaluated in 2017 in two locations in Galicia, (A-D) present each flowering group: very early, early, medium, and late flowering, respectively; SG: stay-green genotype. NSG: non-stay-green; Means \pm std error are presented.

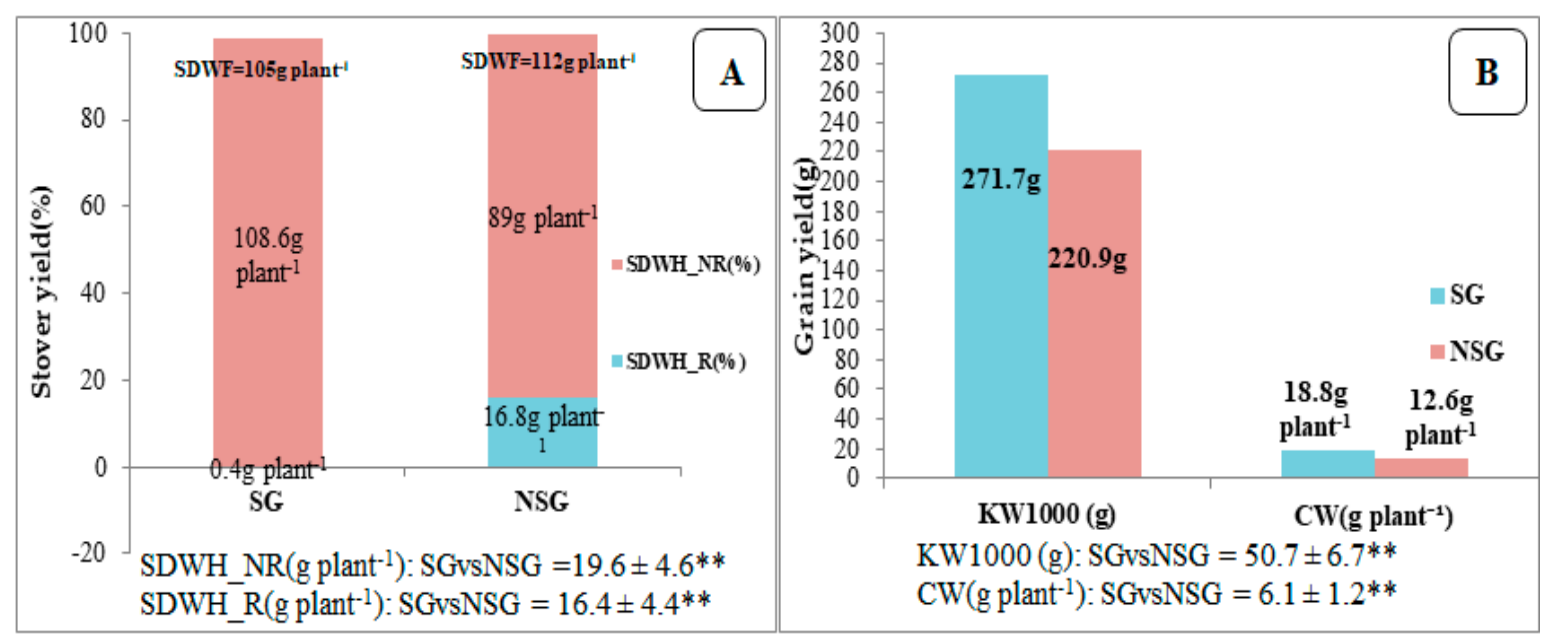

Figure 5. Percentages and means of stover (A) and grain yield (B) of 8 maize SG and 8 NSG lines at harvest, evaluated in 2017 in two locations in Galicia. SDWF: Stover total dry weight at flowering; SDWH_NR: stover dry weight non-remobilized at harvest; SDW_RH: stover dry weight remobilized at harvest. KW1000: kernel weight of $1000 \mathrm{~g}$; CW: cob weight (g plant $\left.{ }^{-1}\right)$; SG: stay-green lines; NSG: non-stay-green lines. ${ }^{* *}$ Significant $p$-value $\leq 0.01$.

The kernels of the SG genotypes were heavier than the NSG genotypes (270 vs. 220 g per 1000 kernels) which explains the higher grain yield of the SG genotypes (80 vs. $60 \mathrm{~g} \mathrm{plant}^{-1}$ ) (Figure 5B, Supplementary Table S2). The cob weight of the SG genotypes was also higher than the NSG genotypes, but not the weight of the secondary ears (Figure 5B, Supplementary Table S2). When we compare SG vs. NSG genotypes, we have a significant difference at $p$-value $\leq 0.01$ only for stover moisture, however, the differences are not significant for kernel and cob moisture, also the moisture of the different parts tended to be higher in the SG genotypes at harvest, although the difference was only significant for the stover (Figure 6; Supplementary Tables S1 and S2). The duration of the grain filling was longer in the SG genotypes (Figure 7, Supplementary Table S1). The comparison of SG vs. NSG genotypes for grain filling days was significant at $p$-value $\leq 0.01$. 


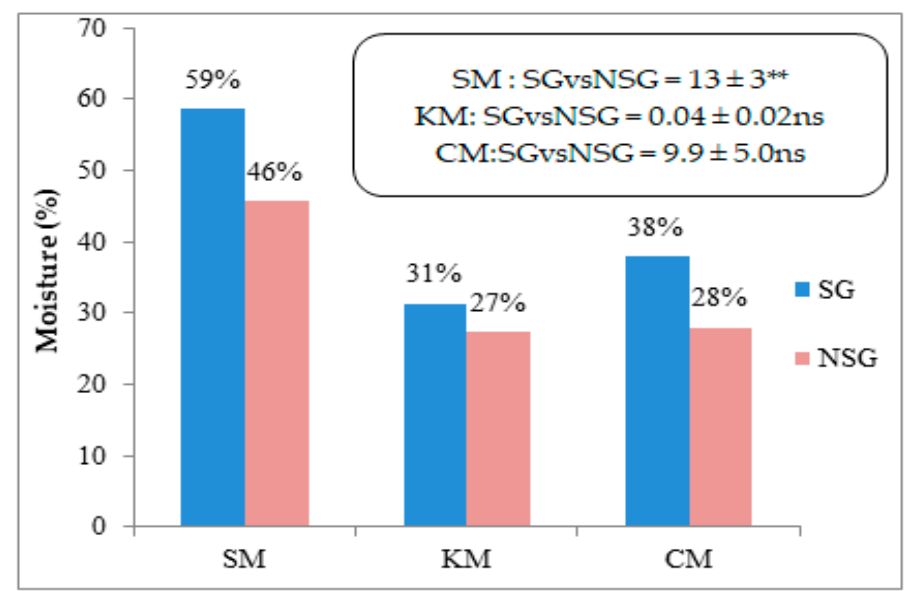

Figure 6. Moisture content in the stover (SM), kernels (KM), and cobs (CM) moisture of 8 maize SG and 8 NSG lines at harvest, evaluated in 2017 in two locations in Galicia. SG: stay-green lines. NSG: non-stay-green lines. ${ }^{* *}$ significant at $p$-value $\leq 0.01$; ns: no significant.

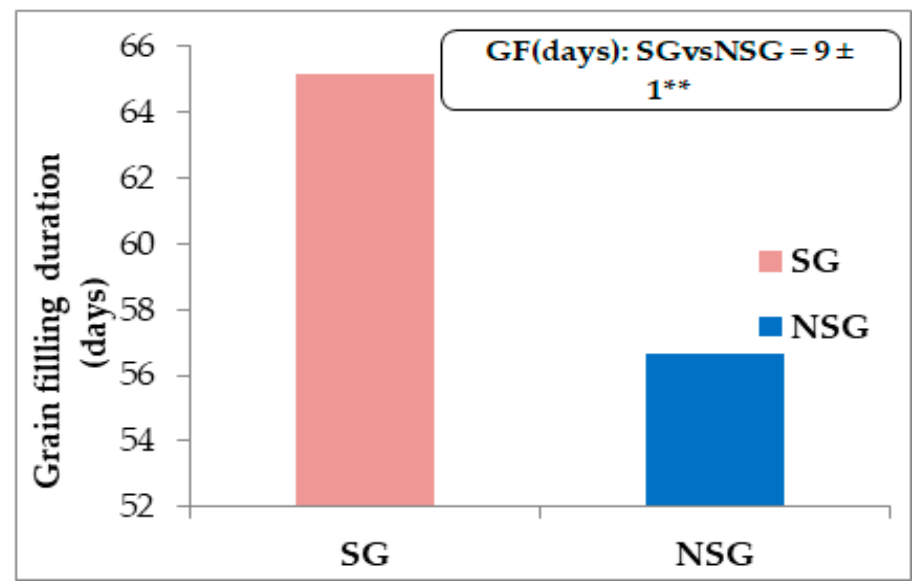

Figure 7. Duration of grain filling (days from flowering to black layer) of SG and NSG genotypes, evaluated in 2017 in two locations in Galicia. SG: stay-green lines. NSG: non-stay-green lines. ** significant at $p$-value $\leq 0.01$.

\subsection{Stover and Kernel N Content}

The amount of $\mathrm{N}$ taken up until flowering was similar in the SG and NSG genotypes (Table 2). However, the $\mathrm{N}$ taken up after flowering was higher in the SG genotypes (1.34 gplant $^{-1}$ ). Thus, the proportion of $\mathrm{N}$ taken up after flowering was 35\% in the SG genotypes and $20 \%$ in the NSG genotypes. As a consequence of the higher absorption after flowering, the total amount of $\mathrm{N}$ taken by plants throughout the complete cycle of life was higher in the SG genotypes $\left(4\right.$ gplant $\left.^{-1}\right)$ than in NSG (3 gplant $\left.{ }^{-1}\right)$ genotypes. Part of the $\mathrm{N}$ stored in leaves and stems was remobilized to the grain (Table 2). The net remobilization was lower in the SG genotypes (35\% of total N uptake) than in the NSG genotypes ( $50 \%$ of total $\mathrm{N}$ uptake) (Table 2). These results show that there is more accumulation of $\mathrm{N}$ in the stover at harvest (1.4gplant ${ }^{-1}$ and 1.2gplant ${ }^{-1}$ ) for SG and NSG genotypes, respectively. There is also a smaller proportion of the kernel $\mathrm{N}$ derived from remobilization ( $40 \%$ vs. $70 \%$ ) in the SG genotypes. However, the higher N uptake in the SG genotypes after flowering compensated for their lower remobilization, resulting in kernels having a larger amount of N (Table 2). For the comparison between SG vs. NSG genotypes, we estimated a significant difference for all traits measured (Table 2), except for TN-UF, where the difference is not significant. 
Table 2. Total $\mathrm{N}$ content at silking time and physiological maturity of plant stover (leaf and stem), $\mathrm{N}$ content in grain, and $\mathrm{N}$ remobilization and uptake by grain of 16 maize inbred lines of four flowering groups from flowering time, evaluated in 2017 in two locations in Galicia.

\begin{tabular}{|c|c|c|c|c|c|c|c|c|c|}
\hline \multirow[b]{2}{*}{ Genotypes } & \multirow[b]{2}{*}{ SG Trait } & \multicolumn{3}{|c|}{ Total N in Plant } & \multicolumn{3}{|c|}{$\mathbf{N}$ in Kernels } & \multicolumn{2}{|c|}{$\mathrm{N}$ in Stover } \\
\hline & & $\begin{array}{c}\mathrm{TN} \\
\left.\text { (gplant }^{-1}\right)\end{array}$ & $\begin{array}{c}\text { TN_UF } \\
\left.\text { gplant }^{-1}\right)\end{array}$ & $\underset{\left.\text { gplant }^{-1}\right)}{\text { TN_AF }}$ & $\begin{array}{c}\text { KN } \\
\left.\text { (gplant }^{-1}\right)\end{array}$ & $\underset{(\%)}{\text { KN_R }}$ & $\underset{(\%)}{\text { KN_NR }}$ & $\underset{\left.\text { (gplant }^{-1}\right)}{\text { SN_R }}$ & $\begin{array}{c}\text { SN_NR } \\
\left.\text { (gplant }^{-1}\right)\end{array}$ \\
\hline F030 & SG & $\begin{array}{c}3.08 \pm \\
0.36\end{array}$ & $\begin{array}{l}2.37(77 \%) \\
\quad \pm 0.37\end{array}$ & $\begin{array}{l}0.70(23 \%) \\
\quad \pm 0.40\end{array}$ & $2.01 \pm 0.54$ & $64 \pm 16$ & $36 \pm 16$ & $\begin{array}{l}1.33(52 \%) \\
\quad \pm 0.47\end{array}$ & $\begin{array}{l}1.04(48 \%) \\
\pm 0.23\end{array}$ \\
\hline P033 & NSG & $\begin{array}{c}2.90 \pm \\
0.37\end{array}$ & $\begin{array}{l}2.17(76 \%) \\
\pm 0.37\end{array}$ & $\begin{array}{c}0.71(24 \%) \\
\pm 0.40\end{array}$ & $2.12 \pm 0.54$ & $65 \pm 16$ & $35 \pm 16$ & $\begin{array}{c}1.42(60 \%) \\
\pm 0.47\end{array}$ & $\begin{array}{c}0.76(39 \%) \\
\pm 0.23\end{array}$ \\
\hline EZ59 & NSG & $\begin{array}{c}2.25 \pm \\
0.36\end{array}$ & $\begin{array}{l}2.66(100 \%) \\
\quad \pm 0.37\end{array}$ & $\begin{array}{c}-0.41 \\
(0 \%) \pm \\
0.40\end{array}$ & $1.24 \pm 0.54$ & $\begin{array}{c}100 \pm \\
16\end{array}$ & 0 & $\begin{array}{l}1.65(56 \%) \\
\pm 0.47\end{array}$ & $\begin{array}{c}1.00(44 \%) \\
\pm 0.23\end{array}$ \\
\hline F05405 & SG & $\begin{array}{c}3.63 \pm \\
0.36\end{array}$ & $\begin{array}{l}2.27(63 \%) \\
\quad \pm 0.37\end{array}$ & $\begin{array}{c}1.36(37 \%) \\
\pm 0.40\end{array}$ & $2.11 \pm 0.54$ & $35 \pm 16$ & $65 \pm 16$ & $\begin{array}{l}0.74(30 \%) \\
\quad \pm 0.47\end{array}$ & $\begin{array}{c}1.52(70 \%) \\
\pm 0.23\end{array}$ \\
\hline OQ403 & NSG & $\begin{array}{c}2.35 \pm \\
0.36\end{array}$ & $\begin{array}{c}1.78(79 \%) \\
\pm 0.37\end{array}$ & $\begin{array}{l}0.56(21 \%) \\
\quad \pm 0.40\end{array}$ & $1.40 \pm 0.54$ & $68 \pm 16$ & $32 \pm 16$ & $\begin{array}{l}0.84(47 \%) \\
\quad \pm 0.47\end{array}$ & $\begin{array}{l}0.94(53 \%) \\
\quad \pm 0.23\end{array}$ \\
\hline PHTE4 & SG & $\begin{array}{c}2.76 \pm \\
0.36\end{array}$ & $\begin{array}{c}1.54(57 \%) \\
\pm 0.37\end{array}$ & $\begin{array}{c}1.21(43 \%) \\
\pm 0.40\end{array}$ & $1.78 \pm 0.54$ & $33 \pm 16$ & $67 \pm 16$ & $\begin{array}{c}0.57(37 \%) \\
\pm 0.47\end{array}$ & $\begin{array}{c}0.97(63 \%) \\
\pm 0.23\end{array}$ \\
\hline EC402 & SG & $\begin{array}{c}4.55 \pm \\
0.36\end{array}$ & $\begin{array}{l}3.13(68 \%) \\
\quad \pm 0.37\end{array}$ & $\begin{array}{l}1.40(32 \%) \\
\pm 0.40\end{array}$ & $2.86 \pm 0.54$ & $48 \pm 16$ & $52 \pm 16$ & $\begin{array}{l}1.47(41 \%) \\
\pm 0.47\end{array}$ & $\begin{array}{c}1.67(59 \%) \\
\pm 0.23\end{array}$ \\
\hline PHBW8 & SG & $\begin{array}{c}3.59 \pm \\
0.36\end{array}$ & $\begin{array}{l}2.67(77 \%) \\
\pm 0.37\end{array}$ & $\begin{array}{l}0.90(23 \%) \\
\quad \pm 0.40\end{array}$ & $2.49 \pm 0.54$ & $62 \pm 16$ & $38 \pm 16$ & $\begin{array}{l}1.60(55 \%) \\
\pm 0.47\end{array}$ & $\begin{array}{c}1.07(45 \%) \\
\pm 0.23\end{array}$ \\
\hline PHG47 & NSG & $\begin{array}{c}2.67 \pm \\
0.36\end{array}$ & $\begin{array}{l}2.03(77 \%) \\
\pm 0.37\end{array}$ & $\begin{array}{l}0.62(23 \%) \\
\pm 0.40\end{array}$ & $1.74 \pm 0.54$ & $63 \pm 16$ & $37 \pm 16$ & $\begin{array}{l}1.13(54 \%) \\
\pm 0.47\end{array}$ & $\begin{array}{l}0.90(46 \%) \\
\pm 0.23\end{array}$ \\
\hline PHK76 & SG & $\begin{array}{c}3.50 \pm \\
0.38\end{array}$ & $\begin{array}{c}2.39(72 \%) \\
\pm 0.40\end{array}$ & $\begin{array}{c}1.11(28 \%) \\
\pm 0.46\end{array}$ & $1.80 \pm 0.56$ & $45 \pm 19$ & $55 \pm 18$ & $\begin{array}{c}0.72(24 \%) \\
\pm 0.50\end{array}$ & $\begin{array}{c}1.68(76 \%) \\
\pm 0.24\end{array}$ \\
\hline SD46 & NSG & $\begin{array}{c}3.18 \pm \\
0.38\end{array}$ & $\begin{array}{c}1.97(72 \%) \\
\pm 0.40\end{array}$ & $\begin{array}{l}1.21(28 \%) \\
\pm 0.46\end{array}$ & $2.07 \pm 0.56$ & $57 \pm 19$ & $44 \pm 18$ & $\begin{array}{l}0.90(48 \%) \\
\pm 0.50\end{array}$ & $\begin{array}{c}1.08(52 \%) \\
\pm 0.24\end{array}$ \\
\hline B73 & NSG & $\begin{array}{c}3.73 \pm \\
0.36\end{array}$ & $\begin{array}{l}2.85(78 \%) \\
\quad \pm 0.37\end{array}$ & $\begin{array}{l}0.83(22 \%) \\
\pm 0.46\end{array}$ & $1.86 \pm 0.54$ & $62 \pm 16$ & $38 \pm 16$ & $\begin{array}{l}1.01(36 \%) \\
\pm 0.47\end{array}$ & $\begin{array}{c}1.82(64 \%) \\
\pm 0.23\end{array}$ \\
\hline PHM10 & NSG & $\begin{array}{c}3.02 \pm \\
0.36\end{array}$ & $\begin{array}{c}2.36(79 \%) \\
\pm 0.37\end{array}$ & $\begin{array}{l}0.62(21 \%) \\
\quad \pm 0.40\end{array}$ & $1.75 \pm 0.54$ & $60 \pm 16$ & $40 \pm 16$ & $\begin{array}{l}1.11(45 \%) \\
\pm 0.47\end{array}$ & $\begin{array}{l}1.23(55 \%) \\
\pm 0.23\end{array}$ \\
\hline РHР38 & SG & $\begin{array}{c}4.15 \pm \\
0.36\end{array}$ & $\begin{array}{l}1.87(53 \%) \\
\pm 0.37\end{array}$ & $\begin{array}{l}2.23(47 \%) \\
\quad \pm 0.40\end{array}$ & $2.48 \pm 0.54$ & $30 \pm 16$ & $70 \pm 16$ & $\begin{array}{l}0.24(26 \%) \\
\quad \pm 0.47\end{array}$ & $\begin{array}{c}1.62(74 \%) \\
\pm 0.23\end{array}$ \\
\hline PHT11 & NSG & $\begin{array}{c}2.99 \pm \\
0.36\end{array}$ & $\begin{array}{l}2.32(80 \%) \\
\pm 0.37\end{array}$ & $\begin{array}{l}0.63(20 \%) \\
\pm 0.40\end{array}$ & $1.43 \pm 0.54$ & $60 \pm 16$ & $40 \pm 16$ & $\begin{array}{l}0.79(34 \%) \\
\pm 0.47\end{array}$ & $\begin{array}{c}1.51(66 \%) \\
\pm 0.23\end{array}$ \\
\hline PHW79 & SG & $\begin{array}{c}4.18 \pm \\
0.36\end{array}$ & $\begin{array}{l}2.29(58 \%) \\
\quad \pm 0.37\end{array}$ & $\begin{array}{l}1.84(42 \%) \\
\pm 0.40\end{array}$ & $2.38 \pm 0.54$ & $25 \pm 16$ & $75 \pm 16$ & $\begin{array}{l}0.53(22 \%) \\
\quad \pm 0.47\end{array}$ & $\begin{array}{c}1.75(78 \%) \\
\pm 0.23\end{array}$ \\
\hline $\begin{array}{l}\text { SG vs. } \\
\text { NSG }\end{array}$ & & $\underset{* *}{0.79 \pm 0.1}$ & $\begin{array}{l}0.05(-16 \%) \\
\pm 0.1^{\mathrm{ns}}\end{array}$ & $\begin{array}{l}0.75(17 \%) \\
\pm 0.14 * *\end{array}$ & $0.54 \pm 0.09^{* *}$ & $\begin{array}{c}-27 \pm 6 \\
* *\end{array}$ & $\underset{* *}{27 \pm 6}$ & $\begin{array}{l}-0.21(-12 \%) \\
\pm 0.10^{*}\end{array}$ & $\begin{array}{l}0.26(12 \%) \\
\pm 0.04^{* *}\end{array}$ \\
\hline
\end{tabular}

\section{Discussion}

The decrease rate in physiologic traits related to photosynthesis (chlorophyll content, $\mathrm{Fv} / \mathrm{Fm}$, and photosynthesis activity measured as $\mathrm{CO}_{2}$ interchange) was faster in NSG than in SG genotypes. Our results of photosynthetic rate, chlorophyll content, and PSII Fv/Fm during senescence agree with previous studies [29-31]. Previous studies have shown that changes in the quantum efficiency of PSII can, to a certain extent, reflect the effect of environmental factors on the plant [32]. Moreover, the physiological changes in the plant itself, such as senescence, can affect the performance of plant photosystems [33]. We found significant differences between SG and NSG genotypes after 45 days from silking. Similar results have been found by Yang et al. [31] and Zhang et al. [34], whose studies show that the decrease was faster for NSG inbred line HZ4, which lost its quantum efficiency of PSII Fv /Fm more quickly after silking than for SG inbred lines. The quantum efficiency 
of PSII was maintained without a significant reduction longer than the photosynthesis activity measured as CO2 interchange. Luo et al. [35] show that the protection of the photosynthetic apparatus of chloroplasts, such as the maintenance of PSII, was indicated as a major contribution to slowing the degeneration of tissues in wheat genotypes with functional stay-green characteristics.

We have found that in the SG genotypes, the photosynthesis was active for a longer period of time, which confirms that the tested maize SG genotypes had a functional staygreen genotype, consistent with the results of [31,34,36-38]. Antonietta et al. [39] found significant differences in photosynthetic rate between SG and NSG genotypes only at the end of the grain filling period, whereas, in our study, the difference between SG and NSG was observed 45 days post-silking until the end of senescence which is between 45 and 60 days for NSG genotypes, and after 60 days for SG genotype.

The advantage of SG for increased grain yield production has been described in many crops, including wheat, sorghum, barley, and rice $[40,41]$. In maize, SG is considered a key trait in modern breeding $[9,16,42]$ and contributed to genetic gains in grain yield over recent decades [6,37]. However, some authors reported a negative effects of SG on grain yield [24,39]. Our results with multiple genotypes evaluated in the same trials confirm that a delayed senescence is positive for stover and grain yield. It is expected that a longer photosynthetic activity provides more photosynthates that integrate throughout a longer duration of grain filling, as we observed in SG genotypes, which leads to higher grain weight [43]. Our study supports this point by proving that SG genotypes show higher grain weight, with a maximum value of $292.5 \mathrm{~g} 1000^{-1}$ kernels for PHW79, the most extreme SG genotype.

The longer period of photosynthesis and grain filling increases the strength of the source (leaves) and sink (kernels) in the SG genotypes, but the accumulation of matter in the stover that we observed in the SG genotypes during the senescence indicates that the stems also work as sinks. This is in line with the results obtained by Borrell et al. [23], who demonstrate the association between stay-green and higher biomass production in sorghum. Similarly, Zhang et al. [34] showed that maize hybrids with a long period of operational photosynthesis activity produced $24 \%$ more stover than NSG hybrids during the grain filling stage. In the NSG genotypes, contrary to SG genotypes, there was a loss of matter in the stover during the senescence, indicating the remobilization of nutrients to the grain. The implications for breeding are: first, the SG genotypes have the potential to increase the grain yield by increasing the strength of the sinks, for example, increasing the ear size and, second, the SG genotypes are valuable for double exploitation, as they produce more stover that could be used for bioenergy. The line PHW79, belonging to the Oh7-Midland heterotic group, was one of the lines with more extreme SG, indicating that this heterotic group could contribute to the breeding of double purpose hybrids (kernel for feed and biomass for biogas) [28]. Contrary to our results, Antonietta et al. [27] reported that SG did not lead to higher post-silking stover production within modern Argentinian hybrids differing in senescence. This could be due to a selection methodology that in Argentina led to an increment in the size of the ears and therefore in the strength of the sinks [39].

The grain nitrogen requirement during kernel filling is met by soil uptake and/or remobilization of reserves taken up before kernel filling and temporarily stored in leaves or stems [44]. Our results are in agreement with studies in sorghum [45] and maize [18,46] that showed that SG genotypes accumulated more $\mathrm{N}$ during the post-silking period than NSG genotypes. Additionally, Mueller and Vyn. [16] and Ning et al. [12] demonstrate that modern SG maize hybrids exhibit greater post-silking $\mathrm{N}$ uptake capacity than older ones. This result was interpreted by [47], who stated that SG is a direct consequence of improved $\mathrm{N}$ balance. Genotypes accumulating more $\mathrm{N}$ during the post-silking period would be able to meet $\mathrm{N}$ demand from kernels without remobilizing excessive amounts of $\mathrm{N}$ from leaves, thereby delaying leaf senescence. Genotypes with longer period of photosynthetic activity are able to provide assimilates to roots that take $\mathrm{N}$ for a longer period of time. Another 
explanation for the relationship between senescence and $\mathrm{N}$ uptake is that the timing of senescence in leaves and roots, which is internally determined and independent of the $\mathrm{N}$ content, determines the uptake of N, not the opposite. Fu et al. [48] show that as the plant $\mathrm{N}$ nutrient status was associated with the stay-green trait, dedicated $\mathrm{N}$ fertilizer management strategies should be specified for different senescence periods of maize genotypes, where the application of $\mathrm{N}$ fertilizer might effectively regulate the $\mathrm{N}$ status of plants and further impact the process of leaf senescence.

In our study, stover $\mathrm{N}$ content declined during the kernel filling period for SG and NSG genotypes, which reflects the remobilization of $\mathrm{N}$ to the growing kernels [24]. In agreement with Kosgey et al. [24], we found that the translocation rate was lower for SG genotypes (35\% of the total N in the stover) compared to NSG genotypes ( $50 \%$ of the total $\mathrm{N}$ in the stover). As a consequence, the proportion of the $\mathrm{N}$ of the kernels that was derived from remobilization in our data was higher in the NSG than in the SG genotypes $(70 \%$ vs. $40 \%$ ). These proportions of $\mathrm{N}$ derived from remobilization are in the range of [49]. However, the higher uptake compensates the lower remobilization and the $\mathrm{N}$ content of the grain is higher in the SG genotypes.

The SG phenotype is associated with greater moisture levels in the stover [50], which is similar to our results. Similar results have been reported by Borrell et al. [23], who found that SG genotypes have higher biomass and kernel moisture [51]. The moisture that we found in the stover of SG lines could be more adequate for ensiling and exploitation of residuals for biogas than the moisture of the NSG lines [52], although more data are needed about the optimum moisture of residuals for ensiling and biogas. We found that, on average, the kernel moisture of the SG lines did not differ statistically from the kernel moisture of the NSG lines, although this result has to be taken cautiously because some of the SG lines had high moisture (around $40 \%$ ) depending on the cycle. Kernel moisture is a very important factor influencing harvest and post-harvest management, and the technological and safety quality of maize grain according to Singh et al. [53] and Maiorano et al. [54]. Breeding for SG should take into account the potential negative effect of the trait increasing kernel moisture.

To overcome the lengthy cycle, the harvest of SG genotypes could be delayed until a point where the autumnal environment does not favor the dry down, or even increases the risk of yield losses due to harsh conditions such as heavy rain or wind. In addition, in the case of rotations, the delay in harvest of the first crop implies a delay in the sowing of the second crop, worsening the environmental conditions for planting and shortening the crop cycle.

\section{Conclusions}

The SG of the inbred lines of maize is functional and associated with higher $\mathrm{N}$ accumulation of matter and uptake after flowering, but a lower $\mathrm{N}$ remobilization rate from stover to kernel. The net effect is higher stover and grain yield and indicates a potential of SG for breeding for a double purpose (grain for feed and stover for bioenergy). However, a potential negative effect of SG on kernel moisture should be controlled when using SG in breeding. There is a concern about the negative effect of stay-green on the nitrogen content of the grain due to the lower remobilization, but our data show that the higher uptake after flowering compensates the lower remobilization.

Supplementary Materials: The following are available online at https:/ / www.mdpi.com/2073-439 5/11/2/276/s1, Table S1: Means, standard errors, and comparison between SG and NSG for stover production of 16 maize inbred lines of four flowering groups, with contrasting Stay-green phenotype evaluated in 2017 in two locations in Galicia, Table S2: Means, standard errors, and comparison between SG and NSG for agronomic characters of 16 maize inbred lines of four flowering groups, with contrasting stay-green phenotype evaluated in 2017 in two locations in Galicia., Table S3: Chlorophyll content (SPAD), Photosynthetics rate $\left(\mu \mathrm{molCO} \mathrm{m}^{-2} \mathrm{~s}^{-1}\right)$ and quantum efficiency of photosystem II $(\mathrm{Fv} / \mathrm{Fm})\left(10^{-3}\right)$ and of maize inbred lines since flowering time, evaluated in 2017 in Tomeza location (Spain). Mean \pm stderrare presented; Table S4: Chlorophyll content (SPAD), Photosynthetics rate 
$\left(\mu \mathrm{mol} \mathrm{CO} \mathrm{CO}^{-2} \mathrm{~s}^{-1}\right)$ and quantum efficiency of photosystem II $(\mathrm{Fv} / \mathrm{Fm})\left(10^{-3}\right)$ and of maize inbred lines since flowering time, evaluated in 2017 in Xinzo location (Spain). Mean \pm stderrare presented. Table S5: Means, standard errors, and comparison between SG and NSG for stover production of maize inbred lines, with contrasting Stay-green phenotype evaluated in 2017 in Tomeza location (Spain). Table S6: Means, Standard errors, and comparison between SG and NSG for agronomic characters of maize inbred lines with contrasting stay-green phenotype evaluated in 2017 in two locations in Tomeza location (Spain). Table S7: Means, Standard errors, and comparison between SG and NSG for stover production of maize inbred lines, with contrasting Stay-green phenotype evaluated in 2017 in Xinzo location (Spain). Table S8: Means, Standard errors, and comparison between SG and NSG for agronomic characters of maize inbred lines with contrasting stay-green phenotype evaluated in 2017 in two locations in Xinzo location (Spain). Table S9: Total N content at silking time and physiological maturity of plant stover (leaf and stem), N-content in grain of maize inbred lines, evaluated in 2017 in Tomeza and Xinzo location.

Author Contributions: B.O. conceived the study and acquired funding; N.C., M.C. and B.O. designed the experiment and recorded the data; N.C, B.O., P.R. and S.M. analyzed the data; N.C.drafted and B.O, P.R., P.M. and S.M. edited the manuscript. All authors have read and agreed to the published version of the manuscript.

Funding: This research was funded by a grant from the "Xunta de Galicia" (Project IN607D 2016/002).

Data Availability Statement: The data presented in this study is available upon request from the corresponding author.

Acknowledgments: We thank the maize breeders that sent us seed of the lines for the study, such as W. Schipprack and A.E. Melchinger (University of Hohenheim), J. Laborde (INRA), J. Moreno (CIAM), Angel Alvarez (CSIC), and particularly M.J. Millard (USDA) who sent all the ExPVP (expired Plant Variety Protection certificate) lines and some of the public lines. We would also to thank the Mediterranean Agronomic Institute of Zaragoza (CIHEAM) for N.C master scholarship during the realizacion of the experiment.

Conflicts of Interest: The authors declare no conflict of interest.

\section{References}

1. Swanckaert, J.; Pannecoucque, J.; Van Waes, J.; Steppe, K.; Van Labeke, M.C.; Reheul, D. Stay-green characterization in Belgian forage maize. J. Agric. Sci. 2017, 155, 766-776. [CrossRef]

2. Trachsel, S.; Sun, D.; SanVicente, F.M.; Zheng, H.; Atlin, G.N.; Suarez, E.A.; Babu, R.; Zhang, X. Identification of QTL for early vigor and stay-green conferring tolerance to drought in two connected advanced backcross populations in tropical maize (Zea mays L.). PLoS ONE 2016, 11, 1-22.

3. Nooden, L.D.; Guiamet, J.J.; Jobn, I. Senescence mechanisms. Physiologia Plantarum 1997, 101, 746-753. [CrossRef]

4. Lim, P.O.; Kim, H.J.; Nam, H.G. Leaf Senescence. Annu. Rev. Plant Biol. 2007, 58, 115-136. [CrossRef] [PubMed]

5. Wei, S.; Wang, X.; Zhang, J.; Liu, P.; Zhao, B.; Li, G.; Dong, S. The role of nitrogen in leaf senescence of summer maize and analysis of underlying mechanisms using comparative proteomics. Plant Science 2015, 233, 72-81. [CrossRef]

6. Valentinuz, O.; Tollenaar, M. Vertical profile of leaf senescence during the grain-filling period in older and newer maize hybrids. Crop Sci. 2004, 44, 827-834.

7. Yang, J.; Zhang, J. Grain filling of cereals under soil drying. New Phytol. 2006, 169, 223-236. [CrossRef]

8. Tollenaar, M.; Ahmadzadeh, A.; Lee, E.A. Physiological basis of heterosis for grain yield in maize. Crop Sci. 2004, 44, 2086-2094. [CrossRef]

9. Lee, E.A.; Tollenaar, M. Physiological basis of successful breeding strategies for maize grain yield. Crop Sci. 2007, 47, 1-14. [CrossRef]

10. Ciampitti, I.; Vyn, T. A comprehensive study of plant density consequences on nitrogen uptake dynamics of maize plants from vegetative to reproductive stages. Field Crop. Res. 2011, 121, 2-18. [CrossRef]

11. Gallais, A.; Coque, M.; Le Gouis, J.; Prioul, J.L.; Hirel, B.; Quilléré, I. Estimating the proportion of nitrogen remobilization and of postsilking nitrogen uptake allocated to maize kernels by nitrogen-15 labeling. Crop Sci. 2007, 47, 685-693.

12. Ning, P.; Li, S.; Yu, P.; Zhang, Y.; Li, C. Post-silking accumulation and partitioning of dry matter, nitrogen, phosphorus and potassium in maize varieties differing in leaf longevity. Field Crop. Res. 2013, 144, 19-27. [CrossRef]

13. Thomas, H.; Howarth, C.J. Five ways to stay green. J. Exp. Bot. 2000, 51, 329-337. [CrossRef] [PubMed]

14. Kante, M.; Revilla, P.; De La Fuente, M.; Caicedo, M.; Ordás, B. Stay-green QTLs in temperate elite maize. Euphytica 2016, 207, 463-473. [CrossRef]

15. Thomas, H.; Ougham, H. The stay-green trait. J. Exp. Bot. 2014, 65, 3889-3900. 
16. Mueller, S.M.; Vyn, T.J. Maize plant resilience to N stress and post-silking N capacity changes over time: A review. Front. Plant Sci. 2016, 7, 1-14. [CrossRef]

17. Bender, R.R.; Haegele, J.W.; Ruffo, M.L.; Below, F.E. Nutrient uptake, partitioning, and remobilization in modern, transgenic insect-protected maize hybrids. Agron. J. 2013, 105, 161-170. [CrossRef]

18. Pommel, B.; Gallais, A.; Coque, M.; Quillere, I.; Hirel, B.; Prioul, J.L.; Andrieu, B.; Floriot, M. Carbon and nitrogen allocation and grain filling in three maize hybrids differing in leaf senescence. Eur. J. Agron. 2006, 24, 203-211. [CrossRef]

19. Luche, H.D.S.; da Silva, J.A.G.; Nornberg, R.; Zimmer, C.M.; Arenhardt, E.G.; da Rosa Caetano, V.; da Maia, L.C.; de Oliveira, A.C. Stay-green effects on adaptability and stability in wheat. Afr. J. Agric. Res. 2015, 10, 1142-1149.

20. Reguera, M.; Peleg, Z.; Abdel Tawab, Y.M.; Tumimbang, E.B.; Delatorre, C.A.; Blumwald, E. Stress-induced cytokinin synthesis increases drought tolerance through the coordinated regulation of carbon and nitrogen assimilation in rice. Am. Soc. Plant Biol. 2013, 163, 1609-1622. [CrossRef]

21. Munaiz, E.D.; Martínez, S.; Kumar, A.; Caicedo, M.; Ordás, B. The senescence (stay-green)—An important trait to exploit crop residuals for bioenergy. Energies 2020, 13, 790. [CrossRef]

22. Zhang, J.; Fengler, K.A.; Van Hemert, J.L.; Gupta, R.; Mongar, N.; Sun, J.; Allen, W.B.; Wang, Y.; Weers, B.; Mo, H.; et al. Identification and characterization of a novel stay-green QTL that increases yield in maize. Plant Biotechnol. J. 2019, 17, 2272-2285. [CrossRef]

23. Borrell, A.; Hammer, G.; Van Oosterom, E. Stay-green: A consequence of the balance between supply and demand for nitrogen during grain filling? Ann. Appl. Biol. 2001, 138, 91-95. [CrossRef]

24. Kosgey, J.R.; Moot, D.J.; Fletcher, A.L.; McKenzie, B.A. Dry matter accumulation and post-silking N economy of 'stay-green' maize (Zea mays L.) hybrids. Eur. J. Agron. 2013, 51, 43-52. [CrossRef]

25. Gregersen, P.L.; Holm, P.B.; Krupinska, K. Leaf senescence and nutrient remobilisation in barley and wheat. Plant Biol. 2008, 10, 37-49. [CrossRef]

26. Chen, K.; Kumudini, S.V.; Tollenaar, M.; Vyn, T.J. Plant biomass and nitrogen partitioning changes between silking and maturity in newer versus older maize hybrids. Field Crops Res. 2015, 183, 315-328. [CrossRef]

27. White, M.R.; Mikel, M.A.; de Leon, N.; Kaeppler, S.M. Diversity and heterotic patterns in North American proprietary dent maize germplasm. Crop Sci. 2020, 60, 100-114. [CrossRef]

28. Mikel, M.A.; Dudley, J.W. Evolution of North American dent corn from public to proprietary germplasm. Crop Sci. 2006, 46, 1193-1205. [CrossRef]

29. Lin, M.; Pang, C.; Fan, S.; Song, M.; Wei, H.; Yu, S. Global analysis of the Gossypium hirsutum L. Transcriptome during leaf senescence by RNA-Seq. BMC Plant Biol. 2015, 15, 1-18. [CrossRef]

30. Wu, X.-Y.; Hu, W.-J.; Luo, H.; Xia, Y.; Zhao, Y.; Wang, L.-D.; Zhang, L.-M.; Luo, J.-C.; Jing, H.-C. Transcriptome profiling of developmental leaf senescence in sorghum (Sorghum bicolor). Plant Mol. Biol. 2016, 92, 555-580. [CrossRef]

31. Yang, Z.; Li, X.; Zhang, N.; Wang, X.; Zhang, Y.; Ding, Y.; Kuai, B.; Huang, X. Mapping and validation of the quantitative trait loci for leaf stay-green-associated parameters in maize. Plant Breed. 2017, 136, 188-196. [CrossRef]

32. Krause, G.H.; Weis, E. Chlorophyll fluorescence and photosynthesis: The basics. Annu. Rev. Plant Physiol. Plant Mol. Biol. 1991, 42, 313-349. [CrossRef]

33. Dai, J.; Gao, H.; Dai, Y.; Zou, Q. Changes in activity of energy dissipating mechanisms in wheat flag leaves during senescence. Plant Biol. 2004, 6, 171-177. [CrossRef] [PubMed]

34. Zhang, Z.; Li, G.; Gao, H.; Zhang, L.; Yang, C.; Liu, P.; Meng, Q. Characterization of photosynthetic performance during senescence in stay-green and quick-leaf-senescence Zea mays L. inbred lines. PLoS ONE 2012, 1-10. [CrossRef]

35. Luo, P.; Ren, Z.; Wu, X.; Zhang, H.; Zhang, H.; Feng, J. Structural and biochemical mechanism responsible for the stay-green phenotype in common wheat. Chin. Sci. Bull. 2006, 51, 2595-2603. [CrossRef]

36. He, P.; Zhou, W.; Jin, J. Effect of nitrogen application on redistribution and transformation of photosynthesized14C during grain formation in two maize cultivars with different senescence appearance. J. Plant Nutr. 2002, 25, 2443-2456. [CrossRef]

37. Ding, L.; Wang, K.J.; Jiang, G.M.; Biswas, D.K.; Xu, H.; Li, L.F.; Li, Y.H. Effects of nitrogen deficiency on photosynthetic traits of maize hybrids released in different years. Ann. Bot. 2005, 96, 925-930. [CrossRef]

38. Caicedo, B.M. Mejora Getética de Maiz Para Senescencia Retrasada 'Stay Green'. Ph.D. Thesis, University Santiago de Compostela, Santiago de Compostela/Lugo, Spain, 2018.

39. Antonietta, M.; Fanello, D.D.; Acciaresi, H.A.; Guiamet, J.J. Senescence and yield responses to plant density in stay green and earlier-senescing maize hybrids from Argentina. Field Crops Res. 2014, 155, 111-119. [CrossRef]

40. Kumari, M.; Singh, V.P.; Tripathi, R.; Joshi, A.K. Variation for staygreen trait and its association with canopy temperature depression and yield traits under terminal heat stress in wheat. In Wheat Production in Stressed Environments; Springer: Dordrecht, The Netherlands, 2007; pp. 357-363.

41. Gous, P.W.; Hickey, L.; Christopher, J.T.; Franckowiak, J.; Fox, G.P. Discovery of QTL for stay-green and heat-stress in barley (Hordeum vulgare) grown under simulated abiotic stress conditions. Euphytica 2016, 207, 305-317. [CrossRef]

42. Wang, Y.; Tang, L.; Hou, Y.; Wang, P.; Yang, H.; Wei, C.-L. Differential transcriptome analysis of leaves of tea plant (Camellia sinensis) provides comprehensive insights into the defense responses to Ectropis oblique attack using RNA-seq. Funct. Integr. Genom. 2016, 16, 383-398. [CrossRef] 
43. Silva, A.S.; de Carvalho, F.I.F.; Nedel, J.L.; Cruz, P.J.; Peske, S.T.; Simioni, D.; Cargnin, A. Enchimento de sementes em linhas quase-isogênicas de trigo com presença e ausência do caráter 'stay-green'. Pesquisa Agropecuaria Brasileira 2003, 38, 613-618. [CrossRef]

44. Uhart, S.A.; Andrade, F.H. Nitrogen and carbon accumulation and remobilization during grain filling in maize under different source/sink ratios. Crop Sci. 1995, 35, 183-190. [CrossRef]

45. Van Oosterom, E.J.; Chapman, S.C.; Borrell, A.K.; Broad, I.J.; Hammer, G.L. Functional dynamics of the nitrogen balance of sorghum. II. grain filling period. Field Crops Res. 2010, 115, 29-38. [CrossRef]

46. Rajcan, I.; Tollenaar, M. Source: Sink ratio and leaf senescence in maize: II. Nitrogen metabolism during grain filling. Field Crops Res. 1999, 60, 255-265. [CrossRef]

47. Subedi, K.D.; Ma, B.L. Nitrogen uptake and partitioning in stay-green and leafy maize hybrids. Crop Sci. 2005, 45, 740-747. [CrossRef]

48. Fu, W.; Wang, Y.; Ye, Y.; Zhen, S.; Zhou, B.; Wang, Y.; Hu, Y.; Zhao, Y.; Huang, Y. Grain yields and nitrogen use efficiencies in different types of stay-green maize in response to nitrogen fertilizer. Plants 2020, 9, 474. [CrossRef]

49. Masclaux-Daubresse, C.; Reisdorf-Cren, M.; Orsel, M. Leaf nitrogen remobilisation for plant development and grain filling. Plant Biol. 2008, 10, 23-36. [CrossRef]

50. Thomas, H.; Smart, C.M. Crops that stay green ${ }^{1}$. Ann. Appl. Biol. 1993, 123, 193-219. [CrossRef]

51. Bekavac, G.; Purar, B.; Stojakovic, M.; Jockovic, D.J.; Ivanovic, M.; Nastasic, A. Genetic analysis of stay-green trait in broad-based maize populations. Cereal Res. Commun. 2007, 35, 31-41. [CrossRef]

52. Melchinger, A.E.; Dhillon, B.S.; Grieder, C.; Orsini, E.; Mittweg, G.; Montes, J.M. Determination of methane fermentation yield and its kinetics by near infrared spectroscopy and chemical composition in maize. J. Near Infrared Spectrosc. 2011, $19,463-477$.

53. Singh, V.; Haken, A.E.; Paulsen, M.R.; Eckhoff, S.R. Starch yield sensitivity of maize hybrids to drying temperature and harvest moisture content. Starch/Staerke 1998, 50, 181-183. [CrossRef]

54. Maiorano, A.; Fanchini, D.; Donatelli, M. MIMYCS. Moisture, a process-based model of moisture content in developing maize kernels. Eur. J. Agron. 2014, 59, 86-95. [CrossRef] 